\title{
Wintertime Water Mass Modification near an Antarctic Ice Front
}

\author{
MARIUS ÅRTHUN AND KeITH W. NiCHOLLS \\ British Antarctic Survey, Cambridge, United Kingdom \\ LARS BOEHME \\ Sea Mammal Research Unit, University of St Andrews, St Andrews, United Kingdom
}

(Manuscript received 28 September 2012, in final form 15 November 2012)

\begin{abstract}
Under ice measurements by seals carrying a miniaturized conductivity-temperature-depth (CTD) instrument fill an important gap in existing observations. Here the authors present data from an instrumented Weddell seal that spent eight consecutive months (February-September) foraging in close proximity to the Filchner Ice Shelf, thus providing detailed information about the evolution of mixed layer hydrography during the austral autumn and winter. The resultant time series of hydrography shows strong seasonal water mass modification, dominated by an upper-ocean $(0-300 \mathrm{~m})$ salinity increase of 0.31 , corresponding to $3.1 \mathrm{~m}$ sea ice growth, and the development of a 500-m thick winter mixed layer. Observations furthermore highlight a gradual salinity increase in a slow $\left(3-5 \mathrm{~cm} \mathrm{~s}^{-1}\right)$ southward flow on the continental shelf, toward the site, and suggest that the inferred ice production is better considered as a regional average rather than being purely local. No clear seasonality is observed in the properties of the underlying Ice Shelf Water.
\end{abstract}

\section{Introduction}

Water mass modification at high latitudes is an important component of the Atlantic meridional overturning circulation (Kuhlbrodt et al. 2007). The densest water mass in the World Ocean, Antarctic Bottom Water (AABW), is formed around the Antarctic continental margins (Orsi et al. 1999). A major source for the precursors of AABW is the southern Weddell Sea continental shelf (Fig. 1) where high rates of sea ice formation and concurrent salinity increase during winter produces High Salinity Shelf Water (HSSW). HSSW contributes to $\mathrm{AABW}$ as it descends the continental slope and interacts with off-shelf water masses. Because sea ice production in the Weddell Sea is associated with the formation of water masses of global significance, it is important to obtain observation-based estimates of the annual rate of ice formation. In situ observations also serve as necessary ground truth for satellite data and are essential for validating ocean models.

Corresponding author address: Marius Årthun, British Antarctic Survey, High Cross, Madingley Road, Cambridge CB3 0ET, United Kingdom.

E-mail:marun@bas.ac.uk
The Southern Ocean and adjacent shelf seas have a pronounced seasonal cycle in sea ice extent, with a maximum in September and minimum in February (Cavalieri and Parkinson 2008). Sea ice in the southern Weddell Sea is mainly formed locally (Nicholls et al. 2009), with production occurring in polynyas, leads, and in the marginal ice zone. Coastal polynyas, areas of open water or thin ice, are maintained throughout the year by wind and tides (Foldvik et al. 2001) and represent regions of locally enhanced sea ice formation. In the southeastern Weddell Sea, polynyas frequently form along the Luitpold Coast and along the Filchner Ice Front (Fig. 1a; e.g., Gordon and Comiso 1988).

Coastal polynyas have a major impact on the salinity distribution in the southeastern Weddell Sea (Markus et al. 1998). Studies of the distribution and seasonal change in upper-ocean salinity below sea ice are, however, limited owing to the scarcity of wintertime hydrography. The region is inaccessible during winter because of sea ice cover and moorings are vulnerable to dredging by icebergs. Model estimates, on the other hand, suffer from coarse resolution. This leads to an inaccurate representation of local topography and winds (Stössel et al. 2011), which is essential for the representation of polynyas, and hence surface buoyancy 

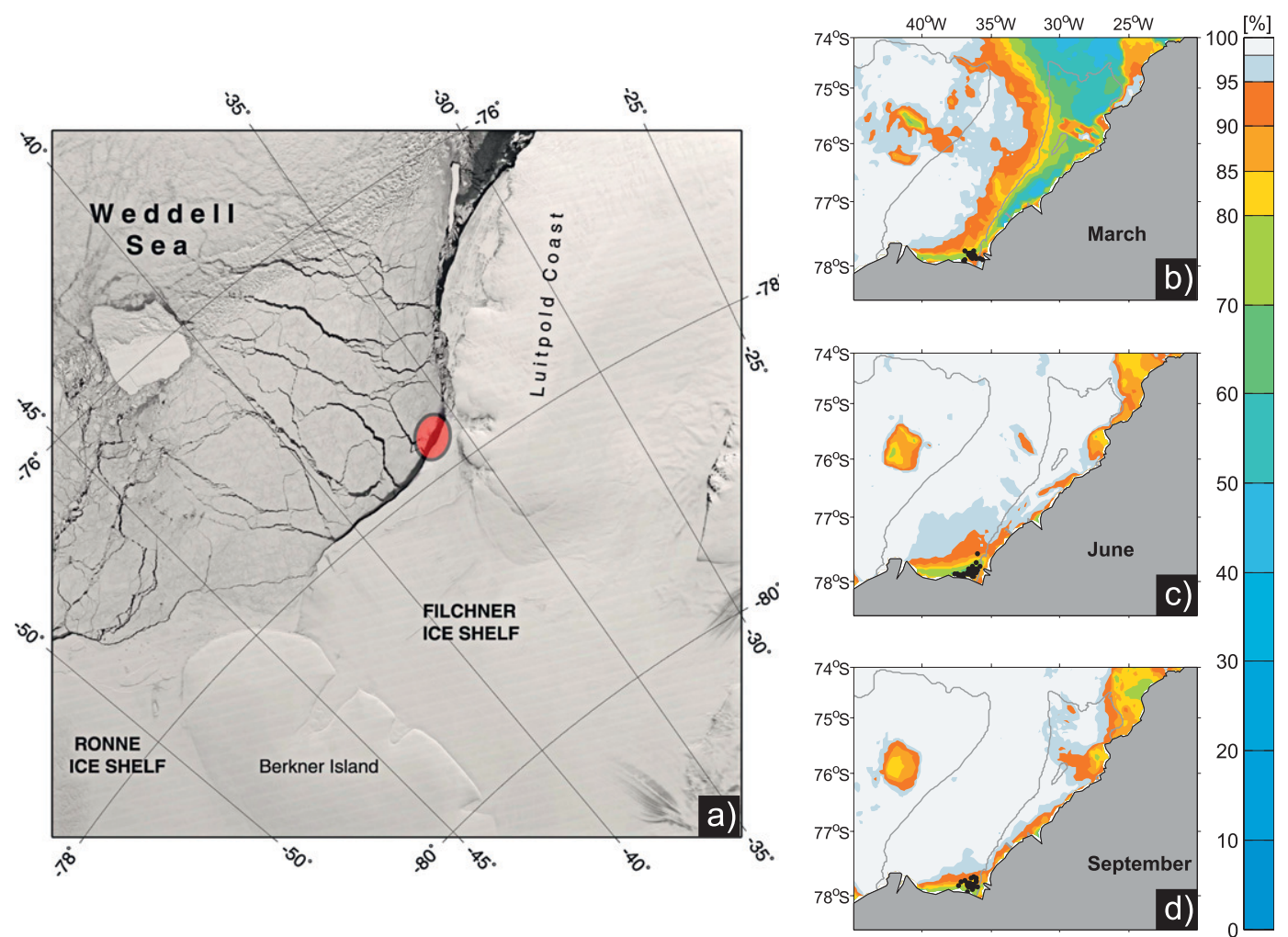

FIG. 1. (a) MODIS image (Scambos et al. 1996) showing the sea ice distribution over the southeastern Weddell Sea continental shelf on 20 Nov 2011. The red circle shows the area where the seal was tagged and subsequently spent the winter. (b)-(d) Satellite derived monthly sea ice concentrations [Advanced Microwave Scanning Radiometer for Earth Observing System (AMSR-E), Spreen et al. (2008)] from 2011. The black dots show the positions of $T-S$ profiles from the instrumented seal. The $500-\mathrm{m}$ isobath is indicated by the gray line. The low sea ice concentration around $76^{\circ} \mathrm{S}, 40^{\circ} \mathrm{W}$ is caused by transient polynyas around the grounded iceberg A23.

fluxes. Our absence of knowledge of how the mixed layer salinity over the continental shelf evolves during the winter is also hampering modeling efforts that use this as their primary forcing when studying the oceanography over the continental shelf, including the subice-shelf region (e.g., Jenkins et al. 2004).

Recent use of instrumented marine mammals (Charrassin et al. 2008; Meredith et al. 2011; Williams et al. 2011) has provided new insight into upper-ocean variability and sea ice formation rates in Antarctic shelf seas. In the study reported here, to elucidate the wintertime hydrography in the Weddell Sea, 19 Weddell seals (Leptonychotes weddellii) were equipped with oceanographic sensors during February 2011. Here we focus on data from one of the seals that spent the following eight months foraging in front of Filchner Ice Shelf, in an area of open water and mobile pack ice (Fig. 1). These yield a unique time series of hydrography from which an estimate of ice production can be inferred. Concurrent data from the shelf to the north also allow us to quantify the salinity increase of the southward flowing coastal current and, thus, to assess the role of advection in the salt budget at the Filchner Ice Front.

\section{Data}

To acquire wintertime observations from the southern Weddell Sea, 19 Weddell seals were equipped with a conductivity-temperature-depth Satellite Relay Data Logger (CTD-SRDL) (Boehme et al. 2009) during February 2011. The tags were manufactured by the Sea Mammal Research Unit, University of St. Andrews and Valeport Ltd, United Kingdom. When in sampling mode, temperature, conductivity, and pressure are measured once per second as the seal ascends. For each profile, 20 temperature $(T)$-salinity $(S)$ pairs are selected at a uniform pressure interval and transmitted via the Argos satellite system. Postcalibration was performed using concurrent ship-based observations at the time of deployment, and the accuracy of the postprocessed data is 0.02 and $0.005^{\circ} \mathrm{C}$ for salinity and temperature (Boehme et al. 2009). 
TABLE 1. Summary of data collected by the Filchner Ice Front seal. The profile interval refers to the average distance between two profiles, while profile standard deviation (STD) is the average distance between any profile and the mean position. Note that the accuracy of the position for each profile is $O(2 \mathrm{~km})$ (Boehme et al. 2009) and can therefore explain some of the variation between positions.

\begin{tabular}{cccccccc}
\hline \hline Start date & End date & Mean position & Number of profiles & Interval & STD & Mean depth & Max depth \\
\hline 15 Feb 2011 & 11 Oct 2011 & $77.86^{\circ} \mathrm{S}, 36.37^{\circ} \mathrm{W}$ & 451 & $4 \mathrm{~km}$ & $7 \mathrm{~km}$ & $489 \mathrm{~m}$ & $932 \mathrm{~m}$ \\
\hline
\end{tabular}

The spatial distribution of all available profiles is shown in Årthun et al. (2012). Here we focus on results from one seal that spent the winter over the southern continental shelf, close to Filchner Ice Shelf (Fig. 1). The seal remained within the immediate vicinity of the ice front (Table 1) and did not show any apparent seasonal bias in foraging location. The data can thus be treated as a Eulerian time series. The profiles have an average depth of $489 \mathrm{~m}$, repeatedly reaching below $600 \mathrm{~m}$ (Fig. 2a).

\section{Results and discussion}

\section{a. Seasonal evolution of hydrography}

Figures $1 \mathrm{~b}-\mathrm{d}$ show the seasonal development of sea ice extent over the southern Weddell Sea continental shelf in 2011. In summer and early autumn (March) the area along the Luitpold Coast is mainly ice free, while a more closed ice pack is found farther west. During winter (June) and spring (September) the whole Weddell Sea is ice covered except for reduced sea ice
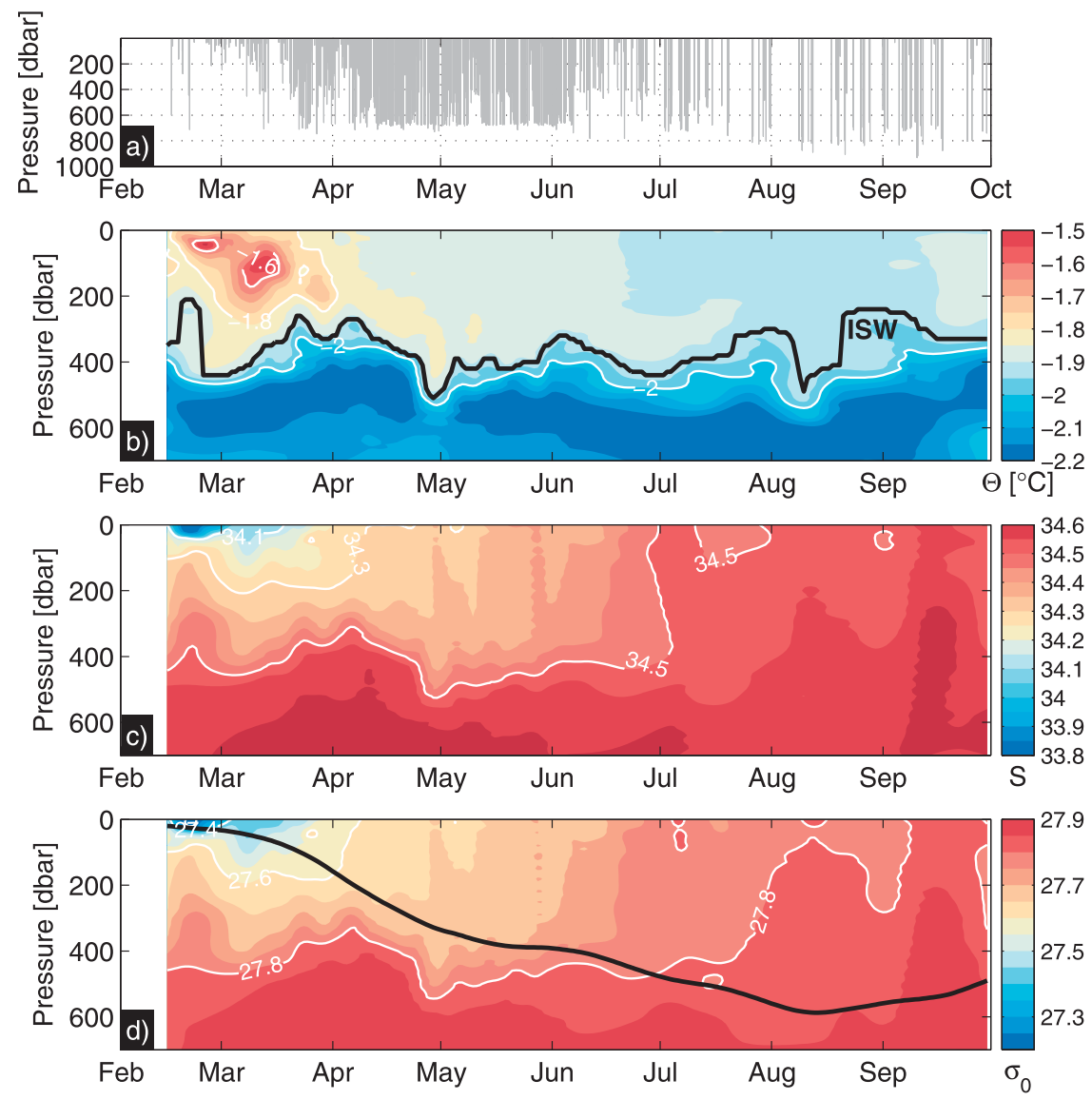

FIG. 2. (a) Temporal and vertical resolution of profiles from the CTD-SRDL and corresponding time series (linearly interpolated onto a $10 \mathrm{dbar}$ by 1-day grid) of (b) potential temperature, (c) salinity, and (d) potential density $\left(\sigma_{0}\right)$. Tick marks indicate the first day of each month. Black line in (b) is the isotherm for the surface freezing point used to define Ice Shelf Water (ISW). In (d) the black line indicates the mixed layer depth, calculated as the depth at which $\sigma_{0}$ increases by $0.05 \mathrm{~kg} \mathrm{~m}^{-3}$ from the surface. The plotted line is the 30 -day running average. 


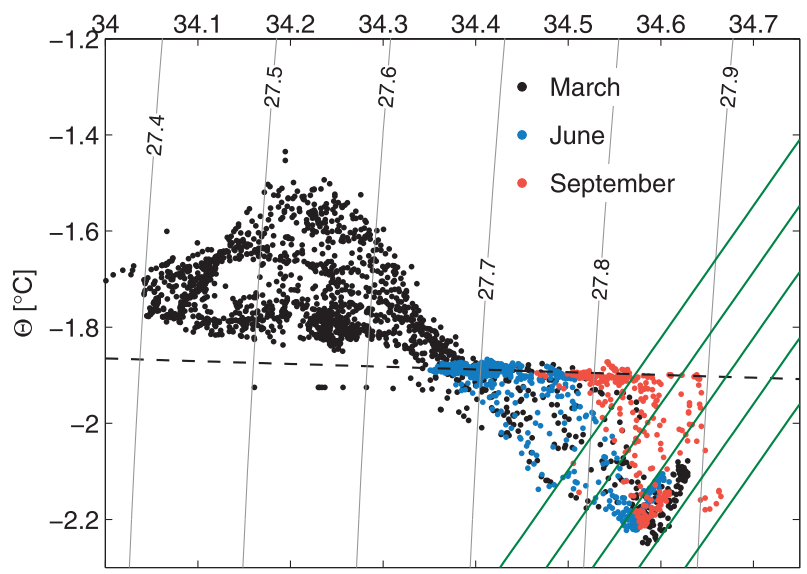

FIG. 3. Potential temperature-salinity $(\Theta-S)$ diagram showing the seasonal change in water mass properties. The black dashed line is the surface freezing temperature, while green solid lines are meltwater mixing lines $\left(2.75^{\circ} \mathrm{C} \mathrm{psu}^{-1}\right)$ showing the trajectory of a water parcel in $\Theta-S$ space as it interacts with the ice shelf base.

concentrations along the coast, the latter a signature of polynya activity. The seasonal sea ice formation is reflected in a cooling of the water column and a gradual increase in salinity (Figs. 2b,c and Fig. 3). During February and March the upper ocean is characterized by a fresh $(S<34.30)$ surface layer and a subsurface temperature maximum $\left(T \sim-1.5^{\circ} \mathrm{C}\right)$. This corresponds to the southward transport of coastal water and modified Warm Deep Water, respectively (Nicholls et al. 2009). A layer of colder Winter Water, a remnant of the previous winter's mixed layer, underlies the surface water, whereas Ice Shelf Water (ISW), identified by temperatures below the surface freezing point, occupies the deeper layer. The upper water column gradually cools, and during mid-March surface temperatures reach the freezing point and surface salinities begin to increase. There is a steady salinity increase in the upper ocean between April and June, by which time the mixed layer salinity reaches 34.50 . The cooling and salinification in autumn and winter are associated with the development of an $\sim 500 \mathrm{~m}$ thick winter mixed layer (Fig. 2d). Except for the shallow halocline in summer, the density gradient at the pycnocline generally amounts to $0.1-0.15 \mathrm{~kg} \mathrm{~m}^{-3}$ over $100 \mathrm{~m}$, until the water column becomes homogeneous in salinity and, hence, density in early winter (Fig. 2d). The maximum salinity at surface freezing temperature in winter, that is, the salinity of HSSW, is 34.64 .

No apparent seasonality is observed in ISW properties. Minimum temperatures, found between 500 and $700 \mathrm{~m}$, range from $-2.20^{\circ}$ to $-2.24^{\circ} \mathrm{C}$ with corresponding salinities between 34.55 and 34.60 . The origin of this ISW can be found by considering the freshening and cooling of HSSW as it interacts with the ice shelf base.

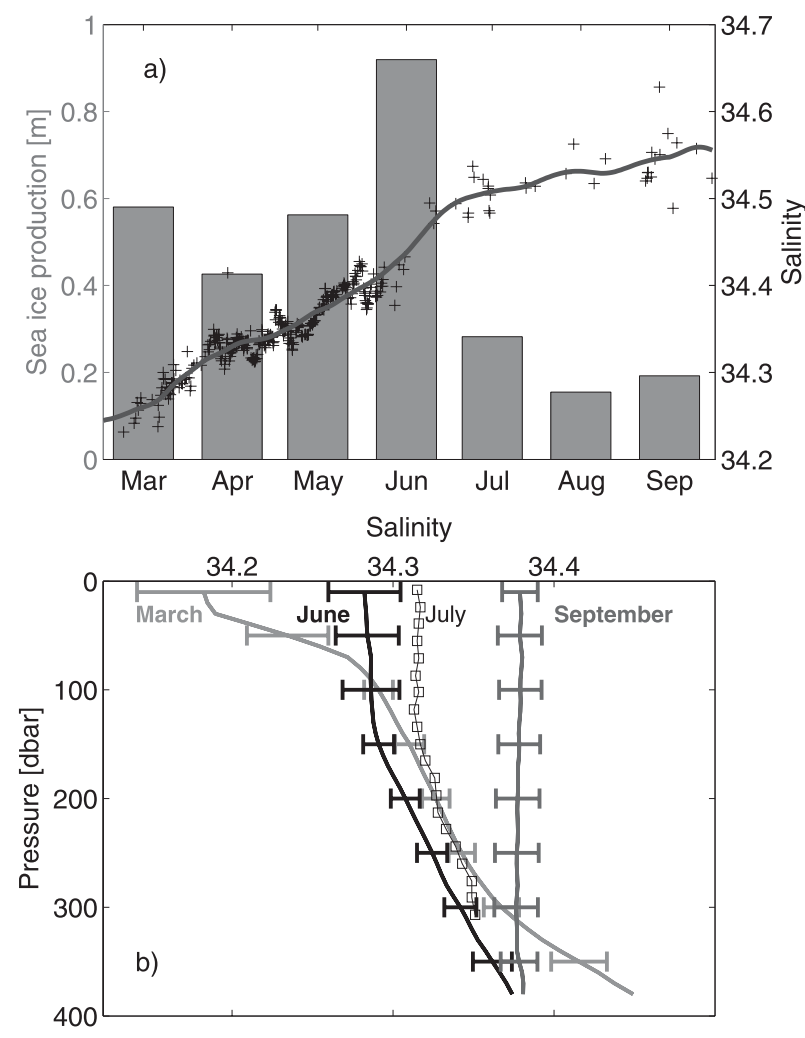

FIG. 4. (a) Calculated sea ice production per unit area (bars) inferred from the seal-derived salinity increase in the upper $300 \mathrm{~m}$ (solid line, crosses show individual salinity measurements). (b) Seasonal salinity evolution based on seal profiles from the northern shelf $\left(75^{\circ}-75.5^{\circ} \mathrm{S}, 28^{\circ}-30^{\circ} \mathrm{W}\right)$ : July profile (open squares) from $74.8^{\circ} \mathrm{S}$, $25.5^{\circ} \mathrm{W}$. Horizontal bars indicate one standard deviation and are drawn every $50 \mathrm{~m}$ based on 38 (March), 16 (June), and 3 (September) profiles, respectively.

Melt water mixing lines (Fig. 3; Nøst and Foldvik 1994) suggest that the parent water mass has a salinity above 34.70 , indicating a source at the western end of the Filchner-Ronne Ice Front. This is consistent with previous measurements at the ice front and beneath the ice shelf (see Nicholls et al. 2009, and references therein).

\section{b. Salinity increase from local sea ice formation and advection}

Following Charrassin et al. (2008) sea ice formation rates can be inferred from the observed salt budget for the upper ocean (0-300 m, Fig. 4a):

$$
\rho_{0} V_{0} S_{0}=\rho_{0} V_{f} S_{f}+\rho_{i} V_{i} S_{i},
$$

where $\rho_{0}=1027 \mathrm{~kg} \mathrm{~m}^{-3}$ is the density of seawater, $V_{0}$ is the initial volume of water with salinity $S_{0}, V_{i}$ is the volume of ice formed with salinity $S_{i}=5$ (Eicken 1992) and density $\rho_{i}=920 \mathrm{~kg} \mathrm{~m}^{-3} ; V_{f}=V_{0}-V_{i}$ is the final 
volume of water with salinity $S_{f}$. Calculations are performed for the period between March and September, although surface temperatures are slightly above freezing point in early March. Observed surface temperature is, however, measured at $8 \mathrm{~m}$ and sea ice can still form on a thin sublayer (Martin and Kauffman 1981). The chosen period is also consistent with the duration of the freezing season in the southern Weddell Sea (Renfrew et al. 2002). The total sea ice production is $3.1 \mathrm{~m}$ (Fig. 4a). Production rates are highest during March to June, values ranging from 0.43 (April) to $0.92 \mathrm{~m} \mathrm{month}^{-1}$ (June). Inferred rates during winter (July-September) are lower $\left(0.16-0.28 \mathrm{~m} \mathrm{month}^{-1}\right)$, reflecting a more consolidated ice pack. Ice formation rates are somewhat sensitive to input parameters; for example, using a sea ice salinity $S_{i}=0.31 S_{w}\left(S_{w}\right.$ : surface salinity, Markus et al. 1998) increases our sea ice production estimate to $3.8 \mathrm{~m}$. We also had to assume a depth range over which the salinity change took place. The $3.1 \mathrm{~m}$ value assumes the upper $300 \mathrm{~m}$. Using, instead, the upper $350 \mathrm{~m}$ or upper $400 \mathrm{~m}$ increases the value to $3.5 \mathrm{~m}$ and $3.8 \mathrm{~m}$ respectively.

Calculating sea ice formation rates based on the local salt budget from seal data assumes a negligible influence of advection and evaporation/precipitation on the total freshwater budget. In support of this, Timmermann et al. (2001) found that sea ice formation and export dominate the seasonal freshwater budget of the inner Weddell Sea. However, low salinity water in the Antarctic Coastal Current is a major source of freshwater to the southeastern continental shelf (Fahrbach et al. 1994) and, thus, needs to be considered here. The salinity of the coastal waters remains low along the eastern coast, east of $20^{\circ} \mathrm{W}$, because of the narrow continental shelf (Fahrbach et al. 1994) and onshore Ekman transport (Nøst et al. 2011). As a result mixed layer salinities on the Filchner continental shelf in summer are low (Fig. 4b). During the freezing season water flowing onto the shelf is able to accumulate salt as it travels southward, and Markus et al. (1998) showed, using a simple model prescribing the coastal current, how salt release in coastal polynyas gradually increases the salinity of a water parcel during its drift from north to south. This is consistent with the 0.16 difference in observed salinity in the upper $300 \mathrm{~m}$ in September between the northern (34.39, Fig. 4b) and southern shelf (34.55, Fig. 4a), and the smaller seasonal salinity increase on the northern shelf $(\Delta S=0.10$, based on mean profiles shown in Fig. 4b) compared with the southern shelf $(\Delta S=0.31)$. Spatially more homogeneous mixed layer salinities in March (0-50 m average \pm one standard deviation is $34.20 \pm 0.03$ and $34.17 \pm 0.06$ in the north and south, respectively)

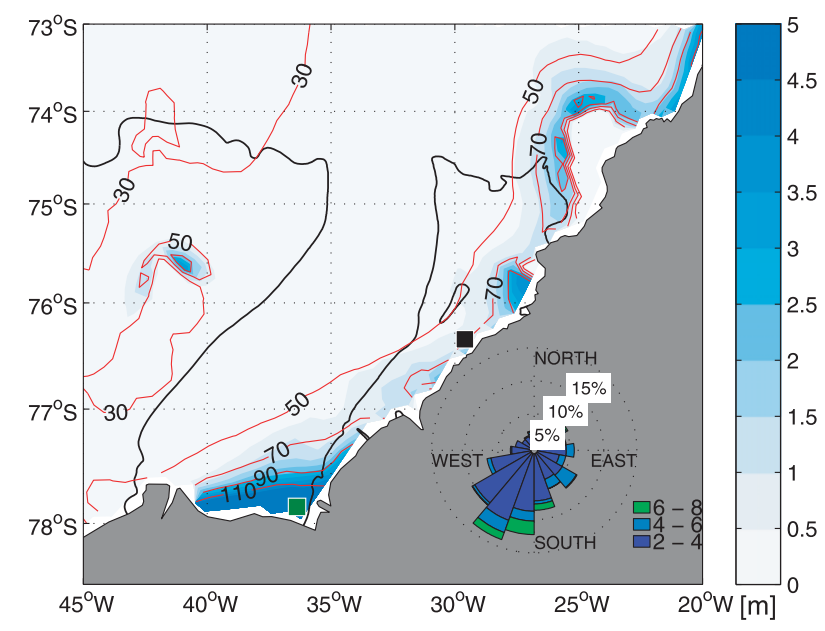

FIG. 5. Satellite-derived (Tamura et al. 2011) sea ice production $(\mathrm{m}$, color axis cut at $5 \mathrm{~m})$ and ERA-Interim heat fluxes $\left(\mathrm{W} \mathrm{m}^{-2}\right.$, red contour lines) between March and September 2011. The black line is the $500-\mathrm{m}$ isobath. The green square indicates the average position of hydrographic profiles. Inset: Compass plot of velocity data $\left[\mathrm{cm} \mathrm{s}^{-1}\right.$, presented as the intensity $(\%)$ of each $20^{\circ}$ bin] from an upward-looking ADCP deployed southwest of Brunt Ice Shelf (black square: $76.35^{\circ} \mathrm{S}, 29.59^{\circ} \mathrm{W}$; depth $301 \mathrm{~m}$ ) between August 2007 and March 2008. The figure is based on hourly averages below $200 \mathrm{~m}$ with tidal signals removed using a low-pass (PL64) filter.

indicate that this difference is mainly a result of winter ice production.

We calculate the drift speed $U$ that would be necessary to account for the observed seasonal (March-September) salinity increase in the upper $300 \mathrm{~m}$ (Fig. 4a) as a result of salt input during the southward drift along the Luitpold Coast, representing a distance $D$ of about $400 \mathrm{~km}$. The total salinity change $(d S / d t)$ can be divided into local $(\partial S / \partial t)$ and advective ( $U \partial S / \partial D$, considering only alongshelf flow) contributions. To account for the salinity increase, assuming that the increase is solely a result of advection $(\partial S / \partial t=0)$ and using the observed salinity gradient between the northern and southern shelf in winter ( $0.16 \pm 0.02$ for June-September; Fig. 4$)$, the speed of the flow must be about $4 \mathrm{~cm} \mathrm{~s}^{-1}$. Few measurements of current speed exist from the southern Weddell Sea continental shelf. Two moorings located in the coastal current off Brunt Ice Shelf between February 2003-05 indicate a mean southward flow of 2-5 $\mathrm{cm} \mathrm{s}^{-1}$ at $\sim 200-300-\mathrm{m}$ depth (40 $\mathrm{m}$ above bottom, Fer et al. 2012), while an upward-looking ADCP deployed further south $\left(76.4^{\circ} \mathrm{S}, 29.6^{\circ} \mathrm{W}\right.$, depth $\left.301 \mathrm{~m}\right)$ between August 2007 and March 2008 yields a mean speed below $200 \mathrm{~m}$ of $3 \mathrm{~cm} \mathrm{~s}^{-1}$ (Fig. 5). This is in general agreement with our inferred accumulation of salt in a slow southwardflowing current. 
Meredith et al. (2011) argued that calculated sea ice formation rates based on upper-ocean salinity changes in an area influenced by advection represent a "smeared average" of ice production for the upstream region, here being the southeastern Weddell Sea continental shelf. The average sea ice formation rate calculated from seal data $\left(I_{p}=0.44 \mathrm{~m} \mathrm{month}^{-1}\right)$ is associated with a heat loss, $Q$, of $53 \mathrm{~W} \mathrm{~m}^{-2}\left(Q=\rho_{i} L_{i} I_{p} ; L_{i}=3.34 \times 10^{5} \mathrm{~J} \mathrm{~kg}^{-1}\right.$ is the latent heat of fusion of ice). This is lower than the average (March-September) heat loss from European Centre for Medium-Range Weather Forecasts Interim Re-Analysis (ERA-Interim) atmospheric data for the continental shelf east of the Filchner Depression $\left(67 \mathrm{~W} \mathrm{~m}^{-2}\right.$, Fig. 5) but close to the value $\left(55 \mathrm{~W} \mathrm{~m}^{-2}\right)$ provided by Eisen and Kottmeier (2000) for newly formed leads in the Weddell Sea. A further comparison can be made with satellitederived ice production estimates from Tamura et al. (2011, data updated to 2011), calculated on a $12.5 \mathrm{~km} \times$ $12.5 \mathrm{~km}$ grid using the thin ice thickness algorithm by Tamura et al. (2007) and ERA-Interim atmospheric data. Estimates of sea ice production in the Weddell Sea presented in Tamura et al. (2008) agree with those of a similar study by Drucker et al. (2011) using different sea ice products and algorithms. For the region occupied by the seal, satellite-derived sea ice formation between March and September is higher than our sea ice production estimate $(6.9 \mathrm{~m}$, Fig. 5), reflecting the large heat loss in the ice front polynya. Along the southeastern Weddell Sea coast (within $50 \mathrm{~km}$ of the coastline between $75-78^{\circ} \mathrm{S}$ ) the average ice production is $1.8 \mathrm{~m}$. This is in close agreement with a recent simulation by Stössel et al. (2011) who found an average annual ice production along the coast of $2.2 \mathrm{~m}$. It is not straightforward to compare these estimates with our hydrography-based estimate $(3.1 \mathrm{~m})$. Nevertheless, it is worth noting that the discrepancy is consistent with additional ice formation taking place in offshore leads (Eisen and Kottmeier 2000) and within the ice covered region (Nicholls et al. 2009), which is included in the observations, but not explicitly represented in satellite-derived datasets or sea ice models because of inadequate resolution and forcing (e.g., Notz 2012). Comparing ice export from the Weddell Sea and sea ice production in coastal polynyas, Drucker et al. (2011) found that $40 \%$ of the total ice production must occur in offshore leads, a number that is in line with the difference in the above estimates. We therefore consider it plausible that the inferred ice production presented here can be considered as an average over the southeastern Weddell Sea continental shelf.

\section{Conclusions}

The properties of the water masses found on the Antarctic continental shelf are of great importance to
Antarctic ice-sheet mass balance (Pritchard et al. 2012) and, hence, global climate. However, as a result of perennially difficult sea ice conditions in situ ocean observations are scarce, especially during winter. Here we have presented a unique eight-month time series of hydrography obtained from an instrumented Weddell seal foraging close to the Filchner Ice Shelf, thus revealing the seasonal evolution of water masses present on the southern Weddell Sea continental shelf. A major seasonal feature is a gradual increase in upper-ocean salinity. This is interpreted as being representative of the average ice production upstream on the continental shelf, which is in accord with inferences from satellite data. Sea ice production, inferred from the observed upper-ocean salt budget, is higher than satellite-derived estimates of ice production in coastal polynyas and demonstrates that additional ice forms in offshore leads and within ice-covered regions. Measurements, like those presented here, of upper-ocean hydrography and its seasonal change are indispensable for evaluating numerical models trying to simulate ice-ocean interaction in the Weddell Sea, which plays an essential role in the formation of dense shelf water and Antarctic Bottom Water.

Acknowledgments. We thank the officers and crew of RRS Ernest Shackleton for their support during cruise ES054, Theoni Photopoulou especially, Takeshi Tamura for providing ice production data, and Keith Makinson for helpful discussions. We also thank Ralph Timmermann and an anonymous reviewer for constructive suggestions that improved the manuscript. This study has received support from NERC-AFI10/5.

\section{REFERENCES}

Årthun, M., K. W. Nicholls, K. Makinson, M. A. Fedak, and L. Boehme, 2012: Seasonal inflow of warm water onto the southern Weddell Sea continental shelf, Antarctica. Geophys. Res. Lett., 39, L17601, doi:10.1029/2012GL052856.

Boehme, L., P. Lovell, M. Biuw, F. Roquet, J. Nicholson, S. E. Thorpe, M. P. Meredith, and M. Fedak, 2009: Technical note: Animal-borne CTD-satellite relay data loggers for realtime oceanographic data collection. Ocean Sci., 5, 685-695, doi:10.5194/os-5-685-2009.

Cavalieri, D. J., and C. L. Parkinson, 2008: Antarctic sea ice variability and trends, 1979-2006. J. Geophys. Res., 113, C07004, doi:10.1029/2007JC004564.

Charrassin, J. B., and Coauthors, 2008: Southern Ocean frontal structure and sea-ice formation rates revealed by elephant seals. Proc. Natl. Acad. Sci. USA, 105, $11634-11639$, doi:10.1073/pnas.0800790105.

Drucker, R., S. Martin, and R. Kwok, 2011: Sea ice production and export from coastal polynyas in the Weddell and Ross Seas. Geophys. Res. Lett., 38, L17502, doi:10.1029/2011GL048668. 
Eicken, H., 1992: Salinity profiles of Antarctic sea ice - field data and model results. J. Geophys. Res., 97 (C10), 15 545-15 557, doi:10.1029/92JC01588.

Eisen, O., and C. Kottmeier, 2000: On the importance of leads in sea ice to the energy balance and ice formation in the Weddell Sea. J. Geophys. Res., 105 (C6), 14 045-14 060.

Fahrbach, E., R. G. Peterson, G. Rohardt, P. Schlosser, and R. Bayer, 1994: Suppression of bottom water formation in the southeastern Weddell Sea. Deep-Sea Res. I, 41, 389-411, doi:10.1016/0967-0637(94)90010-8.

Fer, I., K. Makinson, and K. W. Nicholls, 2012: Observations of thermohaline convection adjacent to Brunt Ice Shelf. J. Phys. Oceanogr., 42, 502-508.

Foldvik, A., T. Gammelsrød, E. Nygaard, and S. Østerhus, 2001: Current measurements near Ronne Ice Shelf: Implications for circulation and melting. J. Geophys. Res., 106 (C3), 44634477.

Gordon, A. L., and J. C. Comiso, 1988: Polynyas in the Southern Ocean. Sci. Amer., 258, 90-97.

Jenkins, A., D. M. Holland, K. W. Nicholls, M. Schröder, and S. Østerhus, 2004: Seasonal ventilation of the cavity beneath Filchner-Ronne Ice Shelf simulated with an isopycnic coordinate ocean model. J. Geophys. Res., 109, C01024, doi:10.1029/2001JC001086.

Kuhlbrodt, T., A. Griesel, M. Montoya, A. Levermann, M. Hofmann, and S. Rahmstorf, 2007: On the driving processes of the Atlantic meridional overturning circulation. Rev. Geophys., 45, RG2001, doi:10.1029/2004RG000166.

Markus, T., C. Kottmeier, and E. Fahrbach, 1998: Ice formation in coastal polynyas in the Weddell Sea and their impact on oceanic salinity. Antarctic Sea Ice: Physical Processes, Interactions and Variability, M. O. Jeffries, Ed., Antarctic Research Series, Vol. 74, American Geophysical Union, 273-292.

Martin, S., and P. Kauffman, 1981: A field and laboratory study of wave damping by grease ice. J. Glaciol., 27, 283-313.

Meredith, M. P., K. W. Nicholls, I. A. Renfrew, L. Boehme, M. Biuw, and M. Fedak, 2011: Seasonal evolution of the upperocean adjacent to the South Orkney Islands, Southern Ocean: Results from a "lazy biological mooring". Deep-Sea Res. II, 58 (13-16), 1569-1579, doi:10.1016/j.dsr2.2009.07.008.

Nicholls, K. W., S. Østerhus, K. Makinson, T. Gammelsrød, and E. Fahrbach, 2009: Ice-ocean processes over the continental shelf of the southern Weddell Sea, Antarctica: A review. Rev. Geophys., 47, RG3003, doi:10.1029/2007RG000250.

Nøst, O. A., and A. Foldvik, 1994: A model of ice-shelf ocean interaction with application to the Filchner-Ronne and Ross Ice Shelves. J. Geophys. Res., 99 (C7), 14 243-14 254.
—- M. Biuw, V. Tverberg, C. Lydersen, T. Hattermann, Q. Zhou, L. H. Smedsrud, and K. M. Kovacs, 2011: Eddy overturning of the Antarctic Slope Front controls glacial melting in the Eastern Weddell Sea. J. Geophys. Res., C11014, 116, doi:10.1029/2011JC006965.

Notz, D., 2012: Challenges in simulating sea ice in earth system models. WIREs Climate Change, 3, 509-526, doi:10.1002/ wcc. 189 .

Orsi, A. H., G. C. Johnson, and J. L. Bullister, 1999: Circulation, mixing, and production of Antarctic Bottom Water. Prog. Oceanogr., 43, 55-109, doi:10.1016/S0079-6611(99)00004-X.

Pritchard, H. D., S. R. M. Ligtenberg, H. A. Fricker, D. G. Vaughan, M. R. van den Broeke, and L. Padman, 2012: Antarctic ice-sheet loss driven by basal melting of ice shelves. Nature, 484, 502-505, doi:10.1038/nature10968.

Renfrew, I. A., J. C. King, and T. Markus, 2002: Coastal polynyas in the southern Weddell Sea: Variability of the surface energy budget. J. Geophys. Res., 107, 3063, doi:10.1029/ 2000JC000720.

Scambos, T., J. Bohlander, and B. Raup, 1996: Images of Antarctic ice shelves. National Snow and Ice Data Center Boulder, $\mathrm{CO}$, digital media. [Available online at http://nsidc.org/data/ iceshelves_images/.]

Spreen, G., L. Kaleschke, and G. Heygster, 2008: Sea ice remote sensing using AMSR-E 89-GHz channels. J. Geophys. Res., 113, C02S03, doi:10.1029/2005JC003384.

Stössel, A., Z. Zhang, and T. Vihma, 2011: The effect of alternative real-time wind forcing on Southern Ocean sea ice simulations. J. Geophys. Res., C11021, 116, doi:10.1029/ 2011JC007328.

Tamura, T., K. I. Ohshima, T. Markus, D. J. Cavalieri, S. Nihashi, and N. Hirasawa, 2007: Estimation of thin ice thickness and detection of fast ice from SSM/I data in the Antarctic Ocean. J. Atmos. Oceanic Technol., 24, 1757-1772.

,-- , and S. Nihashi, 2008: Mapping of sea ice production for Antarctic coastal polynyas. Geophys. Res. Lett., 35, L07606, doi:10.1029/2007GL032903.

,,$---\frac{-}{-}$, and H. Hasumi, 2011: Estimation of Surface heat/ salt fluxes associated with sea ice growth/melt in the Southern Ocean. SOLA, 7, 17-20, doi:10.2151/sola.2011-005.

Timmermann, R., A. Beckmann, and H. H. Hellmer, 2001: The role of sea ice in the freshwater budget of the Weddell Sea, Antarctica. Ann. Glaciol., 33, 419-424.

Williams, G. D., M. Hindell, M. N. Houssais, T. Tamura, and I. C. Field, 2011: Upper ocean stratification and sea ice growth rates during the summer-fall transition, as revealed by Elephant seal foraging in the Adelie Depression, East Antarctica. Ocean Sci., 7, 185-202. 